\title{
Education as Action / The Adventure of Education: Thinking with Arendt and Whitehead
}

Maria Tamboukou, Centre for Narrative Research, UEL

\section{Abstract:}

Understanding and action are central themes in Hannah Arendt's thought and an idea that runs throughout her work is that whenever human beings act, they start processes. It is in this light that she saw education as a process whose aim is to make human beings feel at home in the world. Given the centrality of process in understanding action, early on in her work, Arendt reflected and drew upon the ideas of Alfred Whitehead, the philosopher of process. Education in his thought is an art and an adventure whose object should be to enable students grasp the process of life itself and imagine different worlds. In this light, universities are crucial in creating conditions of possibility for imaginative learning and intellectual adventures. Taking action, process, imagination and adventure as my central ideas, in this paper I make connections between Arendt and Whitehead in an attempt to think about education within and beyond 'dark times'.

Key words: understanding, action, process, imagination, adventure, Arendt, Whitehead

'Education is the point at which we decide whether we love the world enough to assume responsibility for it', Hannah Arendt wrote in her essay 'The Crisis in Education' (2006a, p.193). Although education was never her research field, it was very much at the backdrop of everything she thought and wrote about, given her overall interest in the relation between individuals and human communities. In this paper I make connections between Arendt's approach to education and Alfred Whitehead's philosophical thought. While Arendt highlighted responsibility and love as two components of the educational praxis, education for Whitehead is configured as an art and an adventure and its aim should be to enable students understand Life in all its manifestations. But what is the link between a German political philosopher and a Cambridge mathematician apart from the fact that they both found themselves in the US philosophical scene in the first half of the twentieth century?

There have been several studies deploying the concept of becoming in theoretical discussions in education and beyond. ${ }^{1}$ Deleuze and Guattari's philosophies are central within this lively body of literature, but there is very little reference to Whitehead, the philosopher, who introduced this concept in the first place and who was very influential in Deleuze's thought. As Isabelle Stengers has noted, 'Whitehead's work has remained marginal in the academic world' (2011, p.280). In the same vein Whitehead's influence upon the development of Arent's take of existential thought, particularly in the way she shifted her interest from death to natality - the beginning of life as an unfolding process - has hardly been observed. It is such neglected connections that I explore in this paper. 


\section{Understanding as Process}

Understanding and action are central themes in Arendt's thought and an idea that runs throughout her work is that whenever human beings act, they start processes:

Understanding, as distinguished from having correct information and scientific knowledge, is a complicated process, which never produces unequivocal results. It is an unending activity by which, in constant change and variation, we come to terms with and reconcile ourselves to reality, that is try to be at home in the world (1994, p.307-308).

I want to stay at this Arendtian urge of being or rather becoming 'at home in this world' as it runs like a read thread not only throughout her theoretical work, but also in her personal writings, her letters and correspondences with her friends and mentors: 'Ever since I've known that you both came through the whole hellish mess unharmed, I have felt somewhat more at home in this world again' (Arendt and Jaspers 1992, p.23), she wrote to Karl and Gertrud Jaspers on November 18, 1945, when she resumed her broken correspondence with the philosopher, teacher and supervisor of her doctoral thesis.

What has historically emerged as a crisis of the human condition for Arendt is not the Marxist alienation of human beings from their labour, but the human alienation from the world. We live in a world that does not feel any more as a home to us, she has repeatedly argued throughout her work, since our involvement in the web of human relations and therefore in action is the only way we can feel again 'at home in this world' $(1998,135)$. As Lisa Disch has commented 'homelessness is the loss of a sense of place that is not just geographic but also moral and cultural' (1994, p.173). It is in this process of 'feeling at home in the world' that education becomes so crucial. Its aim is to enable young people to know and come to terms with their past, understand their present through an awareness of what their involvement in the web of human relations means and in this way turn a creative eye to the future. After all, human existence for Arendt is an 'everlasting Becoming' (1996, p.63) and education is instrumental in its multiple formations, particularly as it becomes the motor for acting and thinking. In considering relations between acting and thinking I have followed Arendt's suggestion for a need to reconceptualise thinking not as an abstract process away from the world but as an embodied and embedded practice in the quest for meaning and understanding, central in her notion of vita contemplativa, which runs in parallel with vita activa. ${ }^{2}$ Thinking and acting are inextricably linked for Arendt and their relation is horizontal rather than vertical: "my use of the term vita activa presupposes that the concern underlying all its activities is not the same as and is neither superior nor inferior to the central concern of the vita contemplativa' Arendt has written (1981, p.17). What she has highlighted as a problem however is 'the absence of thinking', the fact that very often we have neither the time or the inclination 'to stop and think' (ibid., p.4). Education thus becomes crucial as a social and cultural milieu where thinking can be cultivated and supported not as a passive state of the mind but as praxis in-the-world-with-others.

In this light, understanding as the aim of education is an unending process for Arendt, it involves thinking, but it is also the inevitable result of human action, the effect of what human beings do to carve a place for themselves in the world. What is also interesting to note here is that reconciliation becomes an inherent component of understanding, although it should be conflated with neither its condition, nor its consequence. Arendt has actually drawn on the French proverb tout comprendre c'est tout pardonner - to understand all is to forgive alljuxtaposing forgiving as a single action to that of understanding as an on-going process, 'the specifically human way of being alive' (1996, p. 308). As a matter of fact understanding runs in a parallel line to life itself, 'it begins with birth and ends with death' (ibid.). 
Given Arendt's thesis on existence as 'everlasting Becoming' (1996, p.63), as well as her interest in the never ending process of understanding as a prerequisite for action, it is not surprising that early on in her work she reflected and drew upon the ideas of Whitehead, the philosopher of process: in the place of the concept of Being we now find the concept of Process', she emphatically noted in the Human Condition (1998, p. 296). In highlighting the fact that the actual objects of knowledge can no longer be things but processes, she cited Whitehead's Concept of Nature, in a lengthy footnote, which reveals how closely she had read his work:

That 'nature is process,' that therefore 'the ultimate fact for sense awareness is an event,' that natural sciences deals only with occurrences, happenings or events, but not with things and that 'apart from happenings there is nothing' (see Whitehead, The Concept of Nature, pp. 53, 15, 66) belongs amongst the axioms of modern natural science in all its branches (1998, p.296).

It might be because of her close reading of Whitehead that in citing the French proverb tout comprendre c'est tout pardonner, as noted above, Arendt was actually following Whitehead's use of the same proverb in his own exposition of understanding in his essay, The Aims of Education (1929a), first delivered as an address to the Educational Section of the International Congress of Mathematicians meeting at Cambridge in 1912: 'By understanding I mean more than a mere logical analysis, though that is included. I mean "understanding" in the sense in which it is used in the Frenc proverb, "To understand all, is to forgive all' (ibid., p.2). Drawing on the utilitarian philosophical tradition that he was obviously well versed in, Whitehead made the link between the usefulness of understanding and the usefulness of education: if education is not useful, what is it?' he asked (ibid.). But hand in hand with utilitarianism went a concept of education as a process of joy and discovery, immanently entangled in the process of life itself. Process is indeed at the heart of Whitehead's philosophy and its configuration is different from the common sense of a word that we are more or less familiar with, as I will discuss next.

'The actual world is a process and process is the becoming of actual entities' Whitehead has famously written in his major philosophical work Process and Reality (1985, p.22). As Michael Halewood has succinctly noted, 'reality for Whitehead, must be considered to be a process rather than some kind of substratum (or "primary substance) which is the task of human knowers to know' (2013, p.20). Process is thus constitutive of experience and 'involves the notion of a creative activity belonging to the very essence of each occasion' (Whitehead 1968, p. 151). Whitehead differentiates however his own approach to process from the long philosophical tradition of flows and fluxes that goes back to Heraclitus. There are two kinds of fluency for Whitehead: the fluency of becoming a particular existent, which he calls 'concrescence' and the fluency whereby an entity that has already become enters a process of new becomings — what he calls 'transition' (Whitehead 1985, p. 210). In marking concrescence and transition as two kinds of fluency in the constitution of reality, Whitehead keeps flux and permanence together in his philosophy: on the one hand there is the problem of following the process wherein each individual unity of experience is realised and on the other comes the recognition that there is some actual world out there, already constituted, 'the stubborn fact which at once limits and provides' according to Whitehead (ibid., p.129). In this light 'the stubborn fact', which belongs to the past, inheres in the flowing present wherein actualities are being constituted. This co-existence of permanence and flux creates conditions of possibility for the future, which is anchored in the present but has not been actualised yet. 
It is precisely Whitehead's attention to the neglected importance of permanence that Arendt has highlighted in her analysis of why 'tradition' matters in education and beyond: 'the crisis of authority in education is most closely connected with the crisis of tradition, that is with the crisis in our attitude towards the realm of the past' she wrote (2006a, p.,190). But as already noted above, this attention to the past is not configured as a nostalgic obsession with what the past carries, but rather as a source of past experiences and knowledges that will facilitate students' transition to the future, 'prepare them in advance for the task of renewing a common world' (ibid., p.193). As in her overall philosophy, natality and new beginnings are crucial in Arendt's take on education: 'the essence of education is natality, the fact that human beings are born into the world', she emphatically noted in the very beginning of her essay, 'The Crisis of Education' (ibid., p.171, emphasis in the original). Taking natality as 'the essence of education' Arendt places education at the heart of politics, since natality and new beginning are also central in her conceptualisation of the political: the essence of all, and in particular of political action is to make a new beginning' she noted in her essay 'Understanding and Politics' (1994, p.321). Within Arendt's conceptualization of the political, freedom is also ontologically inherent in the human condition: 'Because he [sic] is a beginning, man can begin; to be human and to be free are one and the same' Arendt wrote in her essay, 'What is Freedom' (2006b, 166).In thus configuring Arendt's thesis on education as a trialectics between action, freedom, and the possibility of initiating new processes, I now want to make connections with Whitehead's understanding of education as a field where the adventure of ideas can begin.

\section{Education and the adventure of ideas}

Running in parallel with Arendt's configuration as outlined above, education for Whitehead is an art and an adventure whose object should be to enable students understand Life in all its manifestations. This is because 'Whitehead privileges feeling over understanding, and offers an account of experience that is affective rather than cognitive' (Shaviro 2012, p.57). Universities in his view were thus crucial in creating affective conditions for imaginative learning: 'The justification for a university is that it preserves the connection between knowledge and the zest of life, by uniting the young and the old in the imaginative consideration of learning' (Whitehead 1929b, p.93). In flagging up the role of imagination in bringing together learning and life itself Whitehead did not marginalise or downplay the role of education to enlighten: imagination is an integral part of the educational praxis: 'a way of illuminating the facts', he wrote (ibid.). His ideas of what educational praxis should be about is very similar to Arendt's approach in this respect, as they scrutinize the relation between the old and the young, the teachers and the students, the force of imagination and the power of discipline: 'Youth is imaginative, and if the imagination be strengthened by discipline, this energy of imagination can in great measure be preserved through life' Whitehead wrote (ibid.).

In the same vein Arendt had also highlighted the role of teachers not in conveying skills, but rather in passing on subject knowledge that would enable their students to grasp the world instead of moralizing them into it: 'an education without learning is empty and therefore degenerates with great ease into moral - emotional rhetoric' she wrote (2006a, p.192). In this sense Arendt made the distinction between education as the political realm where new beginnings can be imagined and enacted and as a mere instrument of political propaganda or inculcation. It is here that she foregrounded the role of responsibility and love as part of the educational project of making human beings feel at home in this world.

In recognising the transformative role of an imaginative educational praxis, Whitehead has also highlighted the role of experience in consolidating cognitive transpositions and processes. 
The role of teachers as vectors of disciplinary knowledges becomes crucial here: 'the tragedy of the world is that those who are imaginative have but slight experience, and those who are experienced have feeble imaginations [...] The task of a university is to weld together imagination and experience', Whitehead wrote (1929b, p.93). Disciplinary traditions are called here not to play the foucauldian role of ordering and controlling the archives of knowledge, but rather to facilitate passages between the old and the new, become the bridges between imagination and experience: 'Education is discipline for the adventure of life; research is intellectual adventure; and the universities should be homes of adventure shared in common by young and old' (ibid., p.98).

The importance of communication in the educational praxis is crucial for Whitehead: 'Imagination is a contagious disease. It cannot be measured by the yard or weighed by the pound [...] It can only be communicated by a faculty, whose members themselves wear the learning with imagination' (ibid., p.97). Communication through organic involvement in the web of human relations is the backdrop of the human condition itself for Arendt, the very aim of the educational praxis as we have seen above. This is because communication is not something that simply crops up in the world; it is rather a cultural construct, the effect of work and action. Whitehead was very specific in laying out the conditions of possibility for imaginative learning to be enacted: 'The combination of imagination and learning normally requires some leisure, freedom from restraint, freedom from harassing worry, some variety of experiences and the stimulation of other minds diverse in opinion and diverse in equipment' (ibid.). Moreover imagination is in itself a process, it can never be crystallised, condensed or conserved, let alone commodified in any sort of knowledge exchange economy or market, notions and structures that we simply take for granted in contemporary educational discourses and policies. In this context universities should be the places par excellence where education and research should meet:

Do you want your teachers to be imaginative? Then bring them into intellectual sympathy with the young at the most eager, imaginative period of life, when intellects are just entering upon their mature discipline. Make your researchers explain themselves to active minds, plastic and with the world before them; make your young students crown their period of intellectual acquisition by some contact with minds gifted with experience of intellectual adventure (ibid.).

Adventure is a crucial concept for Whitehead, figuring prominently in the title of one of his last books: Adventures of Ideas (1967). In the same way that Arendt highlights the importance of reflection and thinking in opening up the gap between past and future (1981, p.206), Whitehead understands History as a process of throwing light into the past, the present and the future, thus creating an assemblage of time wherein human history becomes synonymous with the adventure of ideas $(1967$, p.3). Historical situatedness and awareness is important for Whitehead as 'in each period there is a general form of the forms of thought' (ibid., p.12) that needs to be understood through education, otherwise it gets confused or lost. When we think we elucidate some facts without inevitably shadowing others, Whitehead argues (ibid., p.44) and in this sense understanding is a mode of excluding 'a background of intellectual incoherence' (ibid., p.47), at the same time of acknowledging that 'the history of ideas is a history of mistakes' (ibid., p.25).

Whitehead has further pointed to the very interesting fact that as a result of scholastic education that was prominent in the $16^{\text {th }}$ and $17^{\text {th }}$ century, the great thinkers of this period, including Spinoza, Leibniz, Bacon and Erasmus amongst others, were not members of university faculties as the imaginative and creative force of their thought could not develop within the restraints and limitations of the university milieus of their era (ibid., p.59). This is 
because the history of ideas is actually the history of its countless experiments, failures and adventures: 'experiment is nothing else than a mode of cooking the facts for the sake of exemplifying the law', Whitehead has provocatively noted (ibid., p.88), but this possibility for 'cooking the facts' does not really work in the human and social sciences, since ' the facts of history, even those of private individual history, are too large a scale' (ibid.) and they always go beyond control. In this context 'human thought only dimly discerns, it misdescribes, and it wrongly associates' (ibid., p.159), while language is always 'incomplete and fragmentary' (ibid., p.227).

The role of education is to acknowledge such limitations and still support the adventure of ideas, the fact that although many elements in our experience are 'on the fringe of consciousness' (ibid., p.163), they are still important and that 'our powers of analysis, and of expression, flickers with our consciousness' (ibid., p.164). Instead of supporting the certainty of analysis, knowledges and ideas, which it can't, education should instead encourage and facilitate 'creativity' a notion that very few know that originates in Whitehead's work: 'creativity is the actualisation of potentiality [...] viewed in abstraction objects are passive, but viewed in conjunction they carry the creativity which drives the world. The process of creation is the form of unity of the Universe' (ibid., p.179). It is in the realm of sustaining and supporting creativity that education takes up artistic dimensions, it becomes the art of inspiring ideas.

Arendt's intellectual career was very similar to the experience of the great thinkers of the $16^{\text {th }}$ and $17^{\text {th }}$ centuries that Whitehead had pointed to above. Although she took up temporary universities positions in the US she persistently refused to get a tenure as she could not bear the stifling atmosphere and administrative loads of universities, although she was more than eager to throw herself in the wild ideas of her students that inspired her thoughts and writing: 'teaching has overstimulated me; sometimes my thoughts seem like flies that sit on me and suck out my life's blood-because I can't shake them off through writing, ${ }^{3}$ she wrote to Heinrich Blücher from Berkeley where she spent the spring term of 1955 as a visiting Professor (Arendt and Blücher 1996, p.260). This was an overall loathing experience however, for reasons well recognisable and sadly much more aggravated today:

I've just come back dead tired from a three-hour office hour that was supposed to have lasted only one hour. I really don't know how this is going to work out. Especially because the department is so incredibly incompetent in all administrative matters that one wastes God knows how much time on the most trivial details, As you can tell I am really angry ${ }^{4}$ (ibid., 230).

Things might have not turned so sore in 1929, when Whitehead was writing that the proper function of a university is the imaginative acquisition of knowledge [and that] a university is imaginative or it is nothing - at least nothing useful' (1929b, p.96). These were still the days that one could also argue that enabling, facilitating and supporting the adventure of ideas could take many forms and that producing printed outputs was only one of them: 'for some of the most fertile minds composition in writing, or in a form reducible to writing, seems to be an impossibility. In every faculty you will find that some of the more brilliant teachers are not among those who publish' Whitehead wrote (ibid., 99).

His observation was very close to Arendt's heart and lived experiences: her husband Heinrich Blücher, never published anything, he did not even have a formal university degree, let alone a $\mathrm{PhD}$; still he was one of the most brilliant philosophy teachers at the New English School for Social Research and later at Bard College continuously inspiring his students to throw themselves in the adventure of ideas and the zest of life. ${ }^{5}$ His thesis was that 'one can't work on one's own 
things if one has to work with young people' ${ }^{6}$ (Arendt and Blücher 1996, p.261); he had thus taken the decision to concentrate on his lectures only: 'Next year I'll most probably give a course on the metaphysical implications of [man's] experience of love. A kind of <philosophy of buman relations $>$ that explores personal, social and political aspects of [man's] relationships"7 (ibid., p.250). Even without publishing, these were still the days when university lectures were original pieces of creative intellectual work and not prescribed thin pieces of aims, objectives and learning outcomes, tailored to be massively delivered and digitally reproduced. They surely had long-lasting effects, but not ones, which were necessarily foreseeable, calculable in advance, or 'clearly transferable.'

\section{Education, Crisis and Critique}

Reflecting on the situation of academic life, as well as the function of the university in the first half of the twentieth century both Whitehead and Arendt could not have possibly foreseen what was to happen at the turn of the second millennium. The historical and cultural conditions were different and the technological advances still very young. When writing about the 'Crisis in Education' in 1954, Arendt had already foreseen that teaching could not be disentangled from its subject matter and that a teacher could not just teach anything just because he or she had aquired some 'skills'. Moreover she had vehemently argued that learning is not coterminous with education: 'one can quite easily teach without educating, and one can go on learning to the end of one's days without for that reason becoming educated' she poignantly wrote (2006a, p. 192).

Little did she know that not only teaching, but also research was to become a matter of generic 'skills', transferable by training ${ }^{8}$ and that universities were about to be transformed to vocational institutions selling degrees with a good price in the market. ${ }^{9}$ Her main argument about how to deal with the crisis was that all we needed was a bit of common sense, love for the future of our children and a sense of responsibility for the world.

In reflecting upon the crisis of education, Arendt tried to see it not as a problem, but rather as an opportunity to rethink questions and problems and for new creative forces to come into play: 'a crisis forces us back to questions themselves [...] a crisis becomes a disaster only when we respond to it with performed judgments, that is, with prejudices' (2006a, 171). Arendt deeply believed that intellectuals had the power to persuade, which was after all what politics should be about. Here she was in full agreement with Whitehead: 'The creation of the worldsaid Plato - is the victory of persuasion over force' (1967, p.83). In this context the role of education should be about teaching people how to listen and understand, how to argue and discuss, in short how to persuade and be persuaded. In highlighting the political significance of persuasion Arendt was also problematising the education-politics relation. Education has been historically related to politics she noted: not only has it become 'an instrument of politics', but also and perhaps more important 'political activity itself was conceived of as a form of education' (2006a, p.173). As a matter of fact Arendt highlighted the disciplinary role of education in the formations of modernity in the sense that education has often been used as the coverage, the pretense of imposing 'coercion without the use of force' (ibid., p.174).

It is in the realm of Realpolitik that the weak link of both Whitehead's and Arendt's views on education lies: what they both failed to understand and evaluate was the intense field of antagonistic power relations within which educational institutions, discourses, practices and figures are inextricably entangled. This is not to say that both thinkers wrote out of the blue or that they were detached from the social and political conditions of their geographies and times. It was on the occasion of the initiation of the new business school at Harvard that 
Whitehead wrote his essay 'University and their functions' as an address to the American Association of the Collegiate Schools of Business in 1927. (Whitehead 1929b). What he suggested was that usefulness and the imagination are not incompatible, but rather interwoven notions of the educational praxis in general and of the expansion of university schools and faculties in particular: 'In the modern complex social organization, the adventure of life cannot be disjointed from intellectual adventure [...] in the complex organization of modern business the intellectual adventure of analysis, and of imaginative reconstruction must precede any successful reorganization' (ibid., p.94). Whitehead was not concerned with the political economy of business organization. He was interested in it as an intellectual project that needed to be imaginative, so as to be effective. When he wrote that to-day business organization requires an imaginative grasp of the psychologies of populations engaged in differing modes of occupation' (ibid.), he was not thinking about the disciplinary gaze and biopolitical technologies of modernity. Power relations, capitalism and conflict were processes that he seems to have taken for granted, or at least they were not among the objects of his research interests or inquiries.

Arendt wrote her essay on the 'Crisis in Education' in 1954, the same year that the United States Supreme Court declared public school segregation unconstitutional,

but four years later she drew on some of the ideas of this essay to respond to the controversy that erupted in the Little Rock High School in Arkansas over their decision to comply with the Supreme Court order (1959a, 1959b). The newspaper images and reports of the racist attack that the nine black students underwent on September 3, 1957 when they first arrived in their white only school angered and problematised Arendt. ${ }^{10}$ Her argument was that young people should not be thrown unprotected in political arenas where they had neither chosen nor had they been prepared to deal with and that it was their parents' and teachers' responsibility to protect them and prepare their gradual insertion in the web of human relations. Her essay was fiercely criticised as practically siding with the arguments of the segregationists and it is still a point of reference for a body of critical engagement for and against her position in matters of politics in general and human rights in particular. ${ }^{11}$

In making the connection between 'The Crisis in Education' and the 'Reflections on Little Rock' what I wanted to show is that Arendt was not interested in the material and political conditions that should underpin the constitution of a cultural or educational institution such as 'the Little Rock', neither was she immersed in the materiality of conflicts. Although she had written about the specific role that education played in the US political framework in her essay on the 'the Crisis in education' (2006a, 170), which was published in the fall of 1958-one year after the 'Little Rock' controversy erupted - she presented herself as 'an outsider' of the situation in the South in her preliminary remarks of the 'Reflections', that was published one year later:

I should like to remind the reader that I am writing as an outsider. I have never lived in the South and have even avoided occasional trips to Southern States because they would have brought me into a situation that I personally would find unbearable. Like most people of European origin I have difficulty in understanding, let alone sharing the common prejudices of Americans in this area. Since what I wrote may shock good people and be misused by bad ones, I should like to make it clear that as a Jew I take my sympathy for the cause of the Negroes as for all oppressed or underprivileged peoples for granted and should appreciate it if the reader did likewise (1959a, 46).

Leaving aside Arendt's idealisation of the European position vis-à-vis slavery and race politics, what I think is particularly striking in the above preface is the explicit way Arendt exposes her physical aversion to conflict situations, which is also reflected I have argued, in the way 
conflicts and antagonisms are also downplayed in her political analyses. Here I agree with Chantal Mouffe's succinct argument that 'the main problem with the Arendtian understanding of 'agonism', is that to put it in a nutshell, it is an 'agonism without antagonism' (2007).

In raising the Realpolitik questions for the arguments of both thinkers, my point is that when dealing with educational policies it is useful not to lose sight of the fact that although persuasion is a desirable political process it cannot always be attainable. What happens then when persuasion fails? I have written elsewhere about the Foucauldian notion of parrhesiathe courage to tell the truth within risky situations and its importance for 'academics in dark times' (see Tamboukou 2012). What I have highlighted in my argument was the force of Bartleby's negative affirmation: 'I would prefer not. ${ }^{12}$ Drawing on Arendt's ideas about education as action, love and responsibility and Whitehead's configuration of it as art, imagination and adventure, I want to move beyond the realm of negative affirmation to a joyful political move: charting lines of flight from striated educational spaces today. ${ }^{13}$ How can this been done? If we stick to Whitehead, we are already in the process of doing it, we have actually been constituted as educational subjects through our entanglement in lines of flight, since we emerge from the world and not the world from us (Whitehead 1985, p. 88), or as Arendt has put it, 'living beings [...] are not just in the world, they are of the world (1981, p.20). The idea of mapping is crucial here however, since it is only when we become aware of the traces and patterns of lines of flight - always, already in motion - that we can avoid being absorbed by the black holes of educational policies in general and the neoliberal university in particular. Education for social change is evolving beneath our eyes: all we have to do is to become immersed in its myriad actions, processes and practices, so that it can become more powerful as it keeps going.

\section{Conclusion: Flying like an aeroplane}

In this paper I have brought together Arendt's and Whitehead's thoughts on education and have looked at them through the concepts of action, love, responsibility, imagination and adventure, within the overall context of process philosophy. What I have argued is that conceptualising education as a creative process enabling and supporting our immanence in, but also emergence from the world, is a useful way of avoiding the errors of what Whitehead has identified as 'the bifurcation of nature' (1964, p.30), quite simply the idea that there is a difference, 'an unbridgeable gap between reality as conceived by scientists and reality as experienced by humans', as Halewood has helpfully explained it (2013, p.8). Conceived as a process, education facilitates the fluency of becomings, while at the same time foregrounds the importance of knowing and understanding - the constitutive role of past formations, 'the stubborn fact' of the past. It is in the realm of process philosophy that Whitehead's idea of imaginative learning can be understood not only in terms of the Arendtian love for and ethical responsibility towards the world, but also as an adventure of understanding through flying. As Whitehead poetically put it:

The true method of discovery is like the flight of an aeroplane. It starts from the ground of particular observation; it makes a flight in the thin air of imaginative generalisation; and it again lands for renewed observation rented acute by rational interpretation. The reason for the success of this method of imaginative rationalization is that, when the method of difference fails, factors, which are constantly present may yet be observed under the influence of imaginative thought (1985, p.5). 
References

Apple, M. 2013. Can education change society? New York: Routledge.

Arendt, H. 1959a. 'Reflections on Little Rock', Dissent 6 (1), 45-56.

Arendt, H. 1959b. 'A Reply to Critics', Dissent 6 (2), 179-181.

Arendt, H., 1981. The Life of the Mind, M. McCarthy, ed. New York: Harcourt.

Arendt, H., 1994. 'Understanding and Politics'. In H. Arendt and J. Kohn, ed. Essays in Understanding: Formation, Exile and Totalitarianism. New York: Schoken Books, 307-327.

Arendt, H., 1996. Love and St Augustine, ed. J., V. Scott and J., C., Stark, eds. Chicago: University of Chicago Press.

Arendt, H., 1998 [1958] The Human Condition. Chicago: University of Chicago Press.

Arendt, H., 2006a [1954] 'The Crisis in Education'. In H. Arendt, Between Past and Future. London: Penguin, 170-193.

Arendt, H., 2006b [1954] 'What is Freedom'. In H. Arendt, Between Past and Future. London: Penguin, 142-169.

Arendt, H., and Blücher, H., 1996. Within Four Walls, the correspondence between Hannab Arendt and Heinrich Blücher, 1936-1968, L. Kohler, ed., P. Constantine, trans. New York: Harcourt.

Arendt, H. and Jaspers, K., 1992. Correspondence 1926-1969, L., Kohler and H., Saner, eds, trans. R. and R. Kimber, trans. New York: Harvest.

Ball, S., J., 2006. Education policy and social class. The selected works of Stephen J. Ball. London: Routledge.

Biesta, G. 2014. The Beautiful Risk of Education. Boulder: Paradigm.

Calhoun, C. and McGowan, J., eds. 1997. Hannab Arendt and the Meaning of Politics. Minneapolis:University of Minnesota Press.

Cole, D., 2011. 'A Defense of Hannah Arendt's "Reflections on Little Rock". Philosophical Topics 39(2), 21-40.

Disch, L., J., 1994. Hannah Arendt and the Limits of Philososphy. Ithaca: Cornell University Press.

Griffiths, M., Honeid, M., Todd, S., Winter, C., eds. 2014. Re-imagining Educational Relationships: Etbics, Politics, Practices. Oxford: Wiley Blackwell.

Halewood, M. 2013. A.N. Whitehead and Social Theory. London: Anthem Press.

Jacoway, E., 2007. Turn Away Thy Son: Little Rock, The Crisio That Shocked The Nation. New York: The Free Press.

Morey, M., 2014. 'Reassessing Hannah Arendt's "Reflections on Little Rock (1959)". Law, Culture and the Humanities 10(1), 88-110

Mouffe, C., 2007. 'Artistic Activism and Agonistic Spaces' in ART\&RESEARCH: A Journal of Ideas, Contexts and Methods, 1 (2), 1-5. Available on line at: http://www.artandresearch.org.uk/v1n2/mouffe.html [Accessed, June 14, 2015]

Semetsky, I., and Masny, D., 2013. Deleuze and Education. Edinburgh: Edinburgh University Press.

Simmons, W., P., 2011. 'Arendt, Little Rock and the Cauterization of the Other'. In W. P. Simmons, ed, Human Rights Law and the Marginalized Other. Cambridge MA: Cambridge University Press, 19-43.

Shaviro, S., 2012. Without Criteria: Kant, Whitehead, Deleuze and Aesthetics. Cambridge MA: MIT Press.

Stengers, I., 2011. Thinking with Whitehead. Cambridge MA: Harvard University Press.

Tamboukou, M., 2010. 'Charting Cartographies of Resistance: Line of Flight in Women Artists' Narratives.' Gender and Education, 22 (6), 679-696.

Tamboukou, M., 2012. 'Truth telling in Foucault and Arendt: Parrhesia, the Pariah and Academics in Dark Times'. Journal of Education Policy, 27 (6), 849-865.

Whitehead, A., N., 1929a. 'The Aims of Education'. In A., N., Whitehead The Aims of Education and other essays. New York: The Free Press, 1-14. 
Whitehead, A., N., 1929b. 'Universities and their Function'. In A., N., Whitehead The Aims of Education and other essays, 91-101.

Whitehead, A., N., 1964 [1920] The Concept of Nature. Cambridge: Cambridge University Press.

Whitehead, A., N., 1967[1933] Adventures of Ideas. New York: Free Press.

Whitehead, A., 1968 [1938] Modes of Thought. New York: Free Press.

Whitehead, A., N., 1985 [1929] Process and Reality [Corrected Edition], eds. D. R. Griffin and D. W. Sheburne, eds. New York: The Free Press.

\footnotetext{
${ }^{1}$ For an overview of this literature, see Semetsky and Masny 2013.

${ }^{2}$ These two notions are discussed in detail in the Human Condition, but Arendt's take on thinking is further developed in her posthumous publication The Life of the Mind (1981).

${ }^{3}$ Hannah Arendt to Heinrich Blücher, letter dated May 25, 1955.

${ }^{4}$ Arendt to Blücher, letter dated February 2, 1955, in ibid., 230.

${ }^{5}$ Although Blücher never published, his lectures are now available on line at the Blücher Archive: http://www.bard.edu/bluecher/index.htm [Accessed June 15, 2015\}

${ }^{6}$ Blücher to Arendt, letter dated May 29, 1955.

${ }^{7}$ Blücher to Arendt, letter dated April 24, 1955.

${ }^{8}$ The problem of reducing research activity to generic skills has attracted a lot of interest in educational studies. For most recent studies see amongst others, Apple 2013, Griffiths et al., 2014, Biesta, 2014.

${ }^{9}$ There is a rich body of literature on the marketization of education where Stephen Ball's work has been formative. For an overview of this literature see, Ball 2006. See also the archive of the Journal of Education Policy.

${ }^{10}$ The nine black students, who had previously underwent a rigorous interview assessing their ability to attend the school were: Melba Patillo Beals, Elizabeth Eckford, Ernest Green, Gloria Ray Karlmark, Carlotta Walls Lanier, Terrance Roberts, Jefferson Thomas, Minnijean Brown Trickey, and Thelma Mothershed Wair. They would later be known as the 'Little Rock Nine.' See Jacoway 2007.

${ }^{11}$ Given the limitations of this paper I cannot expand on this literature here, but for a good overview, see Calhoun and McGowan 1997. For recent debates on the 'Little Rock' controversy, see amongst others Morey 2014, Simmons 2011 and Cole 2011.

${ }^{12}$ I refer here to Herman Melville's well-known story: Bartleby the Scrivener: A Story of Wall Street. See, Tamboukou 2012, p.860.

${ }^{13}$ The notion of 'lines of flight' comes from Gilles Deleuze and Felix Guattari philosophical vocabulary, denoting modes of resistance. For an exposition of the term in educational settings, see Tamboukou 2010.
} 